\title{
BÓL A FUNKCJONOWANIE CHORYCH Z REUMATOIDALNYM ZAPALENIEM STAWÓW
}

\author{
PAIN AND FUNCTIONING OF PATIENTS WITH RHEUMATOID ARTHRITIS \\ Aldona Wróbel ${ }^{1}$, Anna Nawalana ${ }^{1}$, Magdalena Staszkiewicz ${ }^{1}$, Anna Majda² \\ ${ }^{1}$ studentka studiów doktoranckich \\ Uniwersytet Jagielloński Collegium Medicum w Krakowie \\ ${ }^{2}$ Pracownia Teorii i Podstaw Pielęgniarstwa \\ Collegium Medicum Uniwersytet Jagielloński w Krakowie
}

DOI: https://doi.org/10.20883/pielpol.2017.33

\section{STRESZCZENIE}

Wprowadzenie. Reumatoidalne zapalenie stawów (RZS) jest chorobą przewlekłą prowadzącą do deformacji stawów i wymagającą stosowania długotrwałej terapii. Chorzy na RZS zmagają się z uporczywym bólem, sztywnością poranną i obrzękiem stawów. Ból, jako jeden z głównych obszarów życia, wpływa na jakość życia chorych.

Cel. Ocena wpływu bólu na jakość życia chorych na reumatoidalne zapalenie stawów.

Materiał i metody badań. W badaniach wzięło udział 40 osób chorujących na RZS, 40 opiekunów nieprofesjonalnych tych chorych i 36 pielęgniarek sprawujących opiekę nad tymi chorymi. Posłużono się autorskim kwestionariuszem ankiety oraz wykorzystano trzy wystandaryzowane narzędzia badawcze: Skalę Skuteczności Otrzymywanej Opieki (SSOop), Skalę Skuteczności Sprawowanej Opieki (SSSop) oraz Kwestionariusz Nottingham Health Profile (NHP/Profil Zdrowia). Związek między poszczególnymi zmiennymi sprawdzono przy użyciu testu Chi oraz testu korelacji rang Spearmana, przyjmując poziom istotności dla $p<0,05$.

Wyniki. Ponad połowa chorych na RZS cechowała się niską jakością życia uwarunkowaną bólem. Miało to wpływ na pogorszenie funkcjonowania pacjentów z RZS w sferze określonej jako „zainteresowania i hobby”. Wykazano istotną zależność między aktywnością zawodową oraz wiekiem chorego a odczuwaniem bólu podczas chodzenia, stania i siedzenia. Pacjenci będący na rencie i emeryturze istotnie częściej odczuwali ból podczas chodzenia, a mający powyżej 60 lat znamiennie częściej podczas stania i siedzenia. Wykazano istotną zależność między niską jakością życia chorych uwarunkowaną bólem a ich zależnością od opiekunów. Chorzy z niską jakością życia byli bardziej zależni od pielęgniarek i opiekunów nieprofesjonalnych.

Wnioski. Ból stawów towarzyszący RZS obniżał jakość życia chorych na RZS oraz istotnie ograniczał jedną ze sfer życia - zainteresowania i hobby. Niska jakość życia pacjentów z RZS uwarunkowana bólem w większym stopniu uzależnia ich od działań opiekuńczo-pielęgnacyjnych sprawowanych przez pielęgniarki i opiekunów nieprofesjonalnych.

SŁOWA KLUCZOWE: reumatoidalne zapalenie stawów, ból, sfery życia.

\begin{abstract}
Introduction. Rheumatoid arthritis (RA) is a chronic disease leading to deformation of joints and requiring the use of longterm therapy. Patients with RA are struggling with persistent pain, morning stiffness and joints' swelling. Pain, as one of the major areas of life, affects the patients' quality of life.

Aim. The assessment of the impact of pain on the quality of life of patients with rheumatoid arthritis.

Material and methods. The studies involved 40 people suffering from rheumatoid arthritis, 40 non-professional carers of these patients and 36 nurses being also involved in the care. A research questionnaire was used to that purpose as well as three standardized research tools: Scale of Effectiveness of the Obtained Care, Scale of the Efficiency of the Care and the Nottingham Health Profile (NHP/Health Profile) questionnaire. The relatedness amongst the variables was tested using the $\mathrm{Chi}^{2}$ test and the Spearman correlation test, assuming the level significance $p$ $<0.05$.

Results. More than half of the diagnosed patients with RA indicated a low quality of life being affected by pain. This affected the functioning of the patients with rheumatoid arthritis in the area referred to as "interests and hobbies". The research demonstrated a significant relationship between the professional activity and the age of the patient, and the feeling of pain while walking, standing or sitting. The patients claiming pension or retirement felt pain significantly more while walking, and those over 60 years old felt it significantly more frequently while standing or sitting. The research demonstrated a significant correlation between the quality of life of the patients being affected by pain, and their dependence on the caregivers. The patients with a low quality of life were more dependent on nurses and non-professional caregivers.

Conclusions. The joint pain accompanying the RA used to decrease the quality of life of the patients with RA, and substantially limited one of the spheres of life - interests and hobbies. A low quality of life of the patients affected by the RA pain condition makes them more dependent on the care-protective activities exercised by the nurses and the non-professional caregivers.
\end{abstract}

KEYWORDS: rheumatoid arthritis, pain, spheres of life. 


\section{Wprowadzenie}

Reumatoidalne zapalenie stawów (RZS) to choroba przewlekła, układowa, obejmująca tkankę łączną. Występuje na podłożu immunologicznym i ma niewyjaśnioną etiologię. Cechami charakterystycznymi są nieswoiste zapalenia zazwyczaj symetrycznych stawów, występowanie zmian pozastawowych oraz powikłań układowych. Prowadzi to do występowania bólów o różnym charakterze, licznych deformacji stawów, niepełnosprawności oraz przedwczesnej śmierci. Obecnie w Polsce na reumatoidalne zapalenie stawów choruje około 400 tys. osób [1-5]. Naprzemienne występowanie okresów zaostrzeń i remisji, długotrwała i uciążliwa terapia, sztywność poranna, doznania bólowe, powodują obniżenie sprawności fizycznej, co w konsekwencji prowadzi do ograniczenia funkcjonowania chorych na płaszczyźnie społecznej i zawodowej [6-8].

Wśród osób chorujących przewlekle, którym towarzyszą długotrwałe bóle, bardzo często pojawiają się negatywne emocje, takie jak lęk, gniew, bezradność oraz poczucie utraty kontroli nad własnym życiem. Zła kondycja psychiczna chorych ma wpływ na ich skalę cierpienia oraz tolerancję bólu. Niestety, nierzadko spotykanym typem reakcji psychicznej na ból o charakterze przewlekłym jest depresja [9-11].

Zaburzenia funkcjonowania w obszarze fizycznym, społecznym i emocjonalnym bardzo często wymuszają na chorych korzystanie z częściowej, bądź całkowitej pomocy w wykonywaniu czynności dnia codziennego świadczonej przez osoby bliskie (opiekunów nieprofesjonalnych) i profesjonalistów z zakresu medycyny, w tym pielęgniarek. Holistyczne i zindywidualizowane podejście do pacjenta może pomóc mu w walce z przeciwnościami, jakie pojawiają się w trakcie choroby, w tym głównie w walce z bólem i niepełnosprawnością, oraz znacząco poprawić jakość życia [6, 7, 9, 11].

Jakość życia to pojęcie, które można różnorodnie definiować. Jest to termin interdyscyplinarny, gdyż znajduje wydźwięk nie tylko w naukach medycznych, naukach o zdrowiu, ale również w naukach społecznych, takich jak: socjologia, pedagogika, psychologia [13]. Według Siergista oraz Junge jakość życia należy analizować biorąc pod uwagę trzy niezwykle ważne elementy: wskaźniki fizyczne, czyli niepełnosprawność i ból, uwarunkowania psychiczne, definiowane jako samopoczucie jednostki, oraz komponent społeczny analizowany w aspekcie poczucia izolacji, pełnienia i wywiązywania się z ról społecznych [14-15].

\section{Cel pracy}

Głównym celem pracy była ocena wpływu bólu na jakość życia chorych na reumatoidalne zapalenie stawów.
W pracy sformułowano również następujące cele szczegółowe:

- ocena związku między jakością życia chorych na RZS uwarunkowaną bólem a zależnością chorych od pielęgniarek i opiekunów nieprofesjonalnych,

- ocena związku między jakością życia chorych na RZS uwarunkowaną bólem a zmęczeniem fizycznym i psychicznym opiekunów nieprofesjonalnych i pielęgniarek.

\section{Materiał i metody}

Badania przeprowadzono zgodnie z zasadami Deklaracji Helsińskiej, od listopada do grudnia 2015 roku, na oddziale reumatologicznym w Małopolsce. Wyniki badania stanowią integralną część szerszego opracowania.

W badaniach wzięło udział 116 osób, w tym 40 pacjentów chorujących na reumatoidalne zapalenie stawów (czas jaki upłynął od powstania diagnozy, był różny w poszczególnych przypadkach), leczonych zarówno biologicznymi lekami modyfikującymi przebieg choroby (bLMPCH), jak również lekami modyfikującymi przebieg choroby (LMPCH), 40 ich opiekunów nieprofesjonalnch oraz 36 pielęgniarek.

W badaniach wykorzystano metodę sondażu diagnostycznego. Narzędziem badawczym, jakim się posłużono, był autorski kwestionariusz ankiety przeznaczony dla chorych z RZS, zawierający 6 pytań dotyczących ich: płci, wieku, wykształcenia, miejsca zamieszkania, aktywności zawodowej oraz czasu trwania choroby. Kolejną zastosowaną metodą była metoda szacowania. Wykorzystano w niej dwa autorskie wystandaryzowane narzędzia badawcze: Skalę Skuteczności Otrzymywanej Opieki (SSOop) ( $\alpha$-Cronbacha dla opieki otrzymywanej od pielęgniarek - 0,92, dla opieki otrzymywanej od opiekunów nieprofesjonalnych - 0,96), Skalę Skuteczności Sprawowanej Opieki (SSSop) ( $\alpha$-Cronbacha - 0,7) oraz kwestionariusz Nottingham Health Profile (NHP).

Skala SSOop autorstwa własnego przeznaczona jest dla pacjentów chorujących na reumatoidalne zapalenie stawów. Składa się z dwóch części. Pierwsza zawiera 10 twierdzeń dotyczących skuteczności opieki otrzymywanej od „bliskiej osoby”, którą należy rozumieć jako „opiekuna nieprofesjonalnego" (np. krewny, znajomy, sąsiad, opiekunka środowiskowa). Druga część skali dotyczy opieki, która świadczona jest przez pielęgniarki. Stwierdzenia dotyczyły działań opiekuńczo- -pielęgnacyjnych, na przykład „Jakość mojego życia ulega poprawie dzięki pomocy udzielanej przez bliską osobę", „Jakość mojego życia ulega poprawie dzięki pomocy udzielanej mi przez pielęgniarki/pielęgniarzy”. Badani wyrażali swoją opinię dotyczącą skuteczności działań opiekuńczo-pielęgnacyjnych na skali Likerta, gdzie 1 - 
oznaczało zdecydowanie tak, a 5 - zdecydowanie nie. Minimalna liczba punktów, jaką można było zdobyć, to 10, a maksymalna 50 dla każdej z części. Na podstawie uzyskanej liczby punktów można było uzyskać wynik odnoszący się do opinii pacjenta na temat skuteczności opieki otrzymywanej od „opiekuna nieprofesjonalnego" (10-34 pkt. oznaczało niską skuteczność, 35-43 pkt. - średnią, 44-50 pkt. - wysoką) oraz od pielęgniarek (gdzie 10-35 pkt. oznaczało niską skuteczność opieki, 36-40 pkt. - średnią, 41-50 pkt. - wysoką). Im wyższy wynik, tym lepsza opinia na temat skuteczności opieki otrzymywanej od „opiekunów nieprofesjonalnych" oraz pielęgniarek.

W celu oceny jakością życia pacjenta uwarunkowanej bólem a opinią na temat skuteczności otrzymywanej opieki opiekuna nieprofesjonalnego i pielęgniarki wykorzystano jedno z pytań Skali Skuteczności Otrzymywanej Opieki (SSOop). Analogicznie (na podstawie jednego pytania) oceniono zależność między jakością życia chorych na RZS uwarunkowaną bólem a zmęczeniem.

Skala SSSop autorstwa własnego zawiera 12 twierdzeń i przeznaczona jest dla „opiekuna nieprofesjonalnego" oraz personelu pielęgniarskiego. Badani wyrażali swoje opinie na temat działań opiekuńczo-pielęgnacyjnych na skali Likerta, gdzie 1 oznaczało zdecydowanie tak, 5 - zdecydowanie nie. Minimalna liczba punktów, jaką można było zdobyć, to 12 , a maksymalna 60 . Na podstawie ilości uzyskanych punktów można było określić opinię opiekuna na temat skuteczności sprawowanej opieki nad chorymi na RZS. Ustalono przedziały punktowe: 12-43 pkt. oznaczało niską skuteczność, 44-47 pkt. - średnią oraz 48-60 pkt. - wysoką. Analogicznie dokonano ustalenia norm punktowych dla pielęgniarek: 12-45 pkt. - niska skuteczność opieki, 46-50 pkt. - średnia skuteczność opieki, 51-60 pkt. - wysoka skuteczność opieki. Im wyższy wynik punktowy, tym opinia dotycząca sprawowanej opieki była lepsza.

Kwestionariusz NHP w polskiej adaptacji B. Bojarskiej, R. Pikuły i K. Wrześniewskiego (Profil Zdrowia), badający jakość życia, podzielony jest na dwie części. Część pierwsza zawiera 38 twierdzeń, które dotyczą głównych obszarów życia, takich jak: ból, energia, zaburzenia snu, reakcje emocjonalne, ograniczenia ruchowe, społeczna izolacja. Część druga zawiera 7 twierdzeń dotyczących wpływu aktualnego stanu zdrowia na następujące sfery życia: pracę zarobkową, prace domowe, życie towarzyskie, życie rodzinne, życie seksualne, zainteresowania i hobby oraz spędzanie czasu wolnego. Badani na wszystkie twierdzenia zawarte w obu częściach skali odpowiadali „tak” lub „nie”. Im wyższy uzyskany wynik punktowy (więcej odpowiedzi „tak”), tym większe upośledzenie danego obszaru życia, niższa jakość życia chorych [12]. W niniejszym artykule podjęto problematykę bólu chorych na RZS, wpływającego na różne obszary życia. Wynik surowy dla tego obszaru uzyskano poprzez zsumowanie każdej odpowiedzi „tak” na osiem twierdzeń dotyczących bólu (o numerze: 2, 4, 8, 19, 24, 28, 36, 38). Maksymalna liczba uzyskanych punktów to 8 , a minimalna 0 . Autorki przyjęły następujący podział jakości życia uwarunkowanej bólem: $\leqslant 3$ pkt. oznaczało wysoką jakość życia, 4-6 pkt. umiarkowaną, a 7-8 pkt. niską.

Związek między poszczególnymi zmiennymi sprawdzono przy użyciu testu $\mathrm{Chi}^{2}$ oraz testu korelacji rang Spearmana, przyjmując poziom istotności dla $p<0,05$. Analizę wyników przeprowadzono za pomocą Programu Statistica 12.0.

Wśród chorych na RZS były 32 kobiety i 8 mężczyzn. Wiek ankietowanych przedstawiał się następująco: najliczniejszą grupę (15 osób), stanowili badani w przedziale wiekowym 60-79 lat, 14 było w wieku 40-59 lat, 7 między 20. a 39. r.ż., najmniej liczną grupę (4 osoby) stanowili badani - w wieku > 79. r.ż. Większość badanych posiadała wykształcenie zawodowe (17 osób) i pochodziła z miasta (27 osób). 14 osób było na rencie, 13 - na emeryturze, 10 - pracowało, 3 było bezrobotnymi. Na reumatoidalne zapalenie stawów 13 ankietowanych chorowało 6-10 lat, 11 osób 11-20 lat, 9 osób dłużej niż 20 lat, natomiast 7 osób krócej niż 5 lat.

W grupie „opiekunów nieprofesjonalnych” było 25 kobiet i 15 mężczyzn. Wiek respondentów przedstawiał się następująco: 22 osoby były w wieku 40-59 lat, 9 osób między 60. a 79. r. ż., 8 osób między 20. a 39. r. ż., oraz 1 poniżej 20. r. ż. Większość opiekunów miała wyższe wykształcenie (14 osób), mieszkała na wsi (12 osób) i była aktywna zawodowo (26 osób). Wśród badanych 13 - opiekowało się współmałżonkiem, 8 - rodzicem, 6 - dzieckiem, 6 - sąsiadem/-ką, 1 - rodzeństwem, 1 - wujostwem.

W grupie pielęgniarek było $23 \mathrm{w}$ przedziale wiekowym 20-39 lat., 13 miało 40-59 lat. Większość posiadała licencjat pielęgniarstwa (18 kobiet), 13 - tytuł magistra pielęgniarstwa, 5 - średnie wykształcenie medyczne.

\section{Wyniki}

Dokonując analizy wyników surowych zebranych za pomocą kwestionariusza NHP stwierdzono, że 24 badanych posiadało niską jakość życia uwarunkowaną bólem, 11 osób - umiarkowaną, natomiast u 5 pacjentów wykazano wysoką jakość życia.

Zdecydowana większość badanych (35 osób) skarżyła się na ból występujący w nocy, 32 respondentów odczuwało ból podczas chodzenia, 31 ankietowanych twierdziło, że zmiana pozycji sprawia im ból (Tabela 1). 
Tabela 1. Odpowiedzi badanych na stwierdzenia dotyczące bólu w kwestionariuszu NHP

Table 1. The responses to the statements regarding pain (NHP)

\begin{tabular}{|c|c|c|c|}
\hline $\begin{array}{c}\text { Numer twierdzenia } \\
\text { w kwestionariuszu } \\
\text { NHP/ } \\
\text { The number of } \\
\text { claims Question- } \\
\text { naire NHP }\end{array}$ & $\begin{array}{l}\text { Stwierdzenia dotyczące bólu (NHP)/ } \\
\text { Statements regarding pain (NHP) }\end{array}$ & $\begin{array}{l}\text { tak/yes } \\
\text { (n) }\end{array}$ & $\begin{array}{c}\text { nie/no } \\
\text { (n) }\end{array}$ \\
\hline 2 & $\begin{array}{l}\text { Mam bóle w nocy/ } \\
\text { I feel pain in the night }\end{array}$ & 35 & 5 \\
\hline 4 & $\begin{array}{l}\text { Mam nieznośne bóle/ } \\
\text { / feel unbearable pain }\end{array}$ & 26 & 14 \\
\hline 8 & $\begin{array}{l}\text { Zmiana pozycji sprawia mi ból/ } \\
\text { Changing the position makes me ache }\end{array}$ & 31 & 9 \\
\hline 19 & $\begin{array}{l}\text { Odczuwam ból, kiedy chodzę/ } \\
\text { I feel pain when I walk }\end{array}$ & 32 & 8 \\
\hline 24 & $\begin{array}{l}\text { Odczuwam ból, kiedy stoję/ } \\
\text { / feel pain when / stand }\end{array}$ & 24 & 16 \\
\hline 28 & $\begin{array}{l}\text { Mam ciągłe bóle/ } \\
\text { I feel constant pain }\end{array}$ & 22 & 18 \\
\hline 36 & $\begin{array}{l}\text { Odczuwam ból, gdy chodzę po } \\
\text { schodach/ } \\
\text { I feel pain when I walk up the stairs }\end{array}$ & 29 & 11 \\
\hline 38 & $\begin{array}{l}\text { Czuję ból, gdy siedzę/ } \\
\text { I feel pain when I sit }\end{array}$ & 26 & 14 \\
\hline
\end{tabular}

$\mathrm{n}$ - liczba badanych $\mathrm{n}$ - number of subjects

Źródło: opracowanie własne

Source: author's own analysis

Wykazano istotną zależność $\left(\mathrm{Chi}^{2}=0.03 ; p<0,05\right)$ pomiędzy aktywnością zawodową chorych na RZS a odczuwaniem bólu podczas chodzenia. Ból podczas chodzenia częściej odczuwali pacjenci, którzy byli na rencie i emeryturze. Wiek chorego wpływał istotnie na odczuwanie bólu podczas stania i siedzenia $\left(\mathrm{Chi}^{2}=0,002 ; p<0,05\right)$. Bólów tych najczęściej doświadczali chorzy w przedziale wiekowym 60-79 lat.

Zdecydowana większość badanych (35 osób) miała problemy w wykonywaniu prac domowych oraz z pracą zarobkową (33 osoby), 31 ankietowanych przyznało, że ma trudności w realizacji swoich zainteresowań i hobby. Na problemy w kontaktach z rodziną zwróciło uwagę aż 23 respondentów (Tabela 2).

Tabela 2. Odpowiedzi badanych dotyczące sfer życia w kwestionariuszu NHP

Table 2. The responses about spheres of life in the Questionnaire NHP

\begin{tabular}{|c|c|c|}
\hline Sfera życia (NHP)/Sphere of life & $\begin{array}{c}\text { tak/yes } \\
(\mathrm{n})\end{array}$ & $\begin{array}{c}\text { nie/no } \\
\text { (n) }\end{array}$ \\
\hline Praca zarobkowa/Gainful employment & 33 & 7 \\
\hline $\begin{array}{l}\text { Prace domowe (np. sprzątanie, gotowanie, naprawy, inne } \\
\text { prace wokół domu)/Housework (e.g. cleaning, cooking, } \\
\text { repair, other work around the house) }\end{array}$ & 35 & 5 \\
\hline $\begin{array}{l}\text { Życie towarzyskie (spotkania ze znajomymi, pójście do } \\
\text { kawiarni)/Social life (meeting friends, going to cafes) }\end{array}$ & 27 & 13 \\
\hline $\begin{array}{l}\text { Życie rodzinne (tzn. kontakty z domownikami)/ } \\
\text { Family life (i.e. contact with members of the household) }\end{array}$ & 23 & 17 \\
\hline Życie seksualne/Sexual life & 30 & 10 \\
\hline
\end{tabular}

Zainteresowania i hobby (np. sport, sztuka, robótki ręczne, majsterkowanie)/Interests and hobby (e.g. Sports, art, handicrafts, do-it-yourself)

Czas wolny (np. letnie lub zimowe wakacje, weekendy poza domem)/Free time (e.g. a summer or winter holidays, weekends away from home)

$\mathrm{n}$ - liczba badanych; $\mathrm{n}$ - number of subjects

Źródło: opracowanie własne

Source: author's own analysis

Wykazano istotny wpływ niskiej jakości życia uwarunkowanej bólem na zainteresowania i hobby chorego $(r=0,11 ; p<0,05)$. Ból generował problemy $w$ tej sferze życia oraz stanowił duże $w$ niej ograniczenie. Nie wykazano jednak związku między niską jakością życia pacjenta uwarunkowaną bólem a pracą zawodową, pracą domową, życiem rodzinnym, życiem towarzyskim, życiem seksualnym oraz spędzaniem czasu wolnego $(p>0,05)$ (Tabela 3).

Tabela 3. Zależność pomiędzy poziomem jakości życia uwarunkowanej bólem a sferami życia

Table 3. The relationship between quality of life and pain conditioned spheres of life

\begin{tabular}{|c|c|c|c|}
\hline \multirow{2}{*}{$\begin{array}{c}\text { Sfery życia w kwestionariuszu } \\
\text { NHP/ } \\
\text { Sphere of life in the Question- } \\
\text { naire NHP }\end{array}$} & \multicolumn{3}{|c|}{$\begin{array}{c}\text { Poziomy jakości życia } \\
\text { uwarunkowane bólem/ } \\
\text { Levels of quality of pain conditioned life }\end{array}$} \\
\hline & $\begin{array}{l}\text { Niski/ } \\
\text { Low }\end{array}$ & $\begin{array}{l}\text { Umiarko- } \\
\text { wany/ } \\
\text { Moderate }\end{array}$ & $\begin{array}{l}\text { Wysoki/ } \\
\text { High }\end{array}$ \\
\hline $\begin{array}{l}\text { Praca zarobkowa/ } \\
\text { Gainful employment }\end{array}$ & $\begin{array}{l}p>0,05 \\
r=0,18\end{array}$ & $\begin{array}{l}p>0,05 \\
r=0,21\end{array}$ & $\begin{array}{l}p>0,05 \\
r=0,34\end{array}$ \\
\hline $\begin{array}{c}\text { Prace domowe/ } \\
\text { Housework }\end{array}$ & $\begin{array}{l}p>0,05 \\
r=0,21\end{array}$ & $\begin{array}{l}p>0,05 \\
r=0,12\end{array}$ & $\begin{array}{l}p>0,05 \\
r=0,69\end{array}$ \\
\hline $\begin{array}{l}\text { Życie towarzyskie/ } \\
\text { Social life }\end{array}$ & $\begin{array}{l}p>0,05 \\
r=0,25\end{array}$ & $\begin{array}{l}p>0,05 \\
r=0,76\end{array}$ & $\begin{array}{l}p>0,05 \\
r=-0,46\end{array}$ \\
\hline $\begin{array}{l}\text { Życie rodzinne/ } \\
\text { Family life }\end{array}$ & $\begin{array}{l}p>0,05 \\
r=0,05\end{array}$ & $\begin{array}{l}p>0,05 \\
r=0,37\end{array}$ & $\begin{array}{l}p>0,05 \\
r=0,37\end{array}$ \\
\hline $\begin{array}{l}\text { Życie seksualne/ } \\
\text { Sexual life }\end{array}$ & $\begin{array}{l}p>0,05 \\
r=0,20\end{array}$ & $\begin{array}{l}p>0,05 \\
r=0,45\end{array}$ & $\begin{array}{l}p>0,05 \\
r=0,75\end{array}$ \\
\hline $\begin{array}{l}\text { Zainteresowania i hobby/ } \\
\text { Interests and hobby }\end{array}$ & $\begin{array}{l}p<0,05 \\
r=0,11\end{array}$ & $\begin{array}{l}p>0,05 \\
r=0,19\end{array}$ & $\begin{array}{l}p>0,05 \\
r=0,57\end{array}$ \\
\hline $\begin{array}{l}\text { Czas wolny/ } \\
\text { Free time }\end{array}$ & $\begin{array}{l}p>0,05 \\
r=0,36\end{array}$ & $\begin{array}{l}p>0,05 \\
r=0,21\end{array}$ & $\begin{array}{l}p>0,05 \\
r=0,68\end{array}$ \\
\hline
\end{tabular}

p - poziom istotności statystycznej/level of statistical significance; $r$ - korelacja rang Spearmana/Spearman rank correlation

Źródło: opracowanie własne

Source: author's own analysis

Wykazano istotną zależność $(r=0,22 ; p<0,05)$ między niską jakością życia chorych na RZS uwarunkowaną bólem a ich zależnością od opiekunów. Chorzy ci byli bardziej zależni od pielęgniarek i opiekunów nieprofesjonalnych niż chorzy, których jakość życia uwarunkowana bólem była na poziomie umiarkowanym lub wysokim (Tabela 4). 
Tabela 4. Jakość życia uwarunkowana bólem a zależność od pielęgniarek i opiekunów nieprofesjonalnych

Table 4. Quality of life conditioned by pain and dependence on nurses and non-professional caregivers

\begin{tabular}{cc}
\hline $\begin{array}{c}\text { Jakość życia chorych na RZS uwa- } \\
\text { runkowana bólem/Quality of life in } \\
\text { patients with RA conditioned pain }\end{array}$ & $\begin{array}{c}\text { RzS od pielęgniarek i opiekunów } \\
\text { nieprofesjonalnych/ }\end{array}$ \\
$\begin{array}{c}\text { Relationship with dependency of } R A \\
\text { patients on nurses and non-profes- } \\
\text { sional caregivers }\end{array}$ \\
\hline Niska/Low & $p<0,05, r=0,22$ \\
Umiarkowana/Moderate & $p>0,05, r=0,11$ \\
Wysoka/High & $p>0,05, r=0,10$ \\
\hline
\end{tabular}

p - poziom istotności statystycznej/level of statistical significance;

$r$ - korelacja rang Spearmana/Spearman rank correlation

Źródło: opracowanie własne

Source: author's own analysis

Niska jakość życia chorych na RZS uwarunkowana bólem wpływała znamiennie częściej na zmęczenie psychiczne $(r=0,33 ; p<0,05)$ oraz fizyczne $(r=0,28 ; p<$ 0,05 ) opiekunów nieprofesjonalnych i pielęgniarek. Opiekunowie nieprofesjonalni i pielęgniarki znacznie częściej odczuwali zmęczenie psychiczne i fizyczne, sprawując opiekę nad chorymi, u których ból pojawiał się w wielu czynnościach dnia codziennego (Tabela 5).

Tabela 5. Jakość życia uwarunkowana bólem a zmęczenie opiekunów nieprofesjonalnych i pielęgniarek

Table 5. Quality of life conditioned by pain and fatigue of non-professional caregivers and nurses

\begin{tabular}{cc}
\hline $\begin{array}{c}\text { Jakość życia chorych na RZS } \\
\text { uwarunkowana bólem/ } \\
\text { Quality of life in patients with RA } \\
\text { conditioned pain }\end{array}$ & $\begin{array}{c}\text { Związek ze zmęczeniem fizycznym } \\
\text { i psychicznym opiekunów } \\
\text { nieprofesjonalnych i pielęgniarek/ } \\
\text { Relationship with physical and mental } \\
\text { fatigue of non-professional caregivers } \\
\text { and nurses }\end{array}$ \\
\hline Niska/Low & $\begin{array}{c}\text { Fizycznym: } p<0,05, r=0,28 / \text { Physical } \\
\text { Psychicznym: } p<0,05, r=0,33 / \text { Mental }\end{array}$ \\
Umiarkowana/Moderate & $\begin{array}{c}\text { Fizycznym: } p>0,05, r=0,17 / \text { Physical } \\
\text { Psychicznym: } p>0,05, r=0,38 / \text { Mental }\end{array}$ \\
Wysoka/High & $\begin{array}{c}\text { Fizycznym: } p>0,05, r=0,27 / \text { Physical } \\
\text { Psychicznym: } p>0,05, r=0,11 / \text { Mental }\end{array}$ \\
\hline
\end{tabular}

p - poziom istotności statystycznej/level of statistical significance;

$r$ - korelacja rang Spearmana/Spearman rank correlation

Źródło: opracowanie własne

Source: author's own analysis

\section{Dyskusja}

W badaniach własnych stwierdzono, iż ponad połowa pacjentów zadeklarowała niską jakość życia związaną z bólem. Można wnioskować, iż ból znacznie ograniczał respondentów, zniechęcał ich do podejmowania codziennych aktywności życiowych, które jeszcze bardziej nasilały dyskomfort, zwłaszcza w okresie zaostrzeń. Należy zaznaczyć, iż najprostsze czynności-chodzenie po schodach, schylanie się, zmiana pozycji ciała, stają się trudnością dla osoby z RZS, co potwierdzają uzyskane wyniki. Prawie wszyscy badani przyznali, że mają bóle w nocy. W badaniach prowadzonych przez Happach i wsp. w grupie 100 pacjentów 58\% z nich również cierpiało na bóle pojawiające się w nocy [16].

Reumatoidalne zapalenie stawów to choroba, w której procesowi zapalnemu obejmującemu stawy często towarzyszą objawy ogólnoustrojowe, tj. osłabienie, spadek masy ciała, stany podgorączkowe, męczliwość, utrata apetytu [1]. Występujące dolegliwości znacznie obniżają jakość i komfort życia chorego, wielokrotnie czyniąc go osobą, która jest zależna od pomocy innych [17]. Wyniki badań własnych pokazują, iż występuje związek między niską jakością życia chorych z RZS spowodowaną bólem a ich istotnie większą zależnością od opiekunów. Osoby z chorobą reumatyczną wielokrotnie muszą korzystać ze wsparcia, pomocy innych osób podczas wykonywania najprostszych czynności dnia codziennego. Happach i wsp. zwrócili uwage na ważność roli profesjonalistów zdrowia (lekarzy, pielęgniarek, psychologów, fizjoterapeutów) w opiece nad osobami chorymi na RZS. Badacze zasugerowali, iż ból przewlekły i stan psychiczny pacjenta są czynnikami, które wymagają największej troski [16].

W badaniach własnych podeszły wiek chorego to czynnik, który wpływał na częstsze odczuwanie bólu podczas „prostych” czynności, takich jak stanie czy siedzenie, w porównaniu z pacjentami młodszymi. Mogło to wynikać nie tylko z licznych deformacji stawów, pojawiających się w miarę postępu choroby i znacznie ograniczających motorykę i uzależniających osobę chorą od pomocy personelu medycznego i bliskich osób, ale także z chorób współistniejących w tym wieku, dodatkowo potęgujących odczuwany dyskomfort. Badania Ejdys dotyczące problemów zdrowotnych i pielęgnacyjnych pacjentów z zapalnymi układowymi chorobami tkanki łącznej wykazały, że największym problemem badanych (>50\% stanowiły osoby w podeszłym wieku) były dolegliwości bólowe zajętych stawów [18].

Pacjenci konsekwentnie oceniają ból jako jeden z czynników najbardziej decydujących o ich jakości życia. Pomimo że jest to odczucie subiektywne, jest ono całościowym wyznacznikiem aktywności choroby dla pacjenta i jego wpływu na ich codzienne funkcjonowanie [19]. Potwierdzeniem tego są wyniki badań własnych, w których wykazano istotną zależność między niską jakością życia uwarunkowaną bólem a ograniczeniami w aspekcie zainteresowań oraz hobby.

Mówiąc o bólu u chorych na RZS, koniecznie trzeba zwrócić uwagę na rodzaj stosowanej terapii farmakologicznej. Badania prowadzone przez Wysocką-Skurską i wsp. wśród 100 pacjentów chorych na RZS dowio- 
dły, że dolegliwości bólowe występujące u pacjentów stosujących terapię lekami biologicznymi powodowały gorszą ocenę jakości ich życia w sferze funkcjonowania fizycznego niż u pacjentów leczonych klasycznymi lekami modyfikującymi przebieg choroby [20]. W niniejszych badaniach nie uwzględniono analizy wyników badań pod względem stosowanej terapii chorych na reumatoidalne zapalenie stawów.

Niezwykle ważne jest monitorowanie bólu u osób z RZS przez osoby z najbliższego otoczenia-opiekunów profesjonalnych (tj. pielęgniarki, opiekunów medycznych) oraz nieprofesjonalnych (tj. rodzinę, przyjaciół, sąsiadów). Określanie poziomu dolegliwości bólowych może przyczynić się do wdrożenia odpowiedniego leczenia oraz zastosowania właściwie dobranego sposobu pielęgnacji, który nie nasila dyskomfortu. Działania te mają na celu zapewnienie jak najlepszego komfortu życia mimo zmagania się z przewlekłą i wyczerpującą chorobą, jaką jest RZS.

\section{Wnioski}

1. Ból stawów towarzyszący RZS obniża jakość życia chorych na RZS oraz istotnie ogranicza jedną ze sfer życia - zainteresowania i hobby.

2. Niska jakość życia pacjentów z RZS uwarunkowana bólem w większym stopniu uzależnia ich od działań opiekuńczo-pielęgnacyjnych sprawowanych przez pielęgniarki i opiekunów nieprofesjonalnych.

3. Niska jakość życia pacjentów z RZS uwarunkowana bólem zwiększa zmęczenie fizyczne i psychiczne opiekunów nieprofesjonalnych i pielęgniarek.

4. Istnieje konieczność zwrócenia uwagi na ból występujący u chorych na RZS wśród pielęgniarek i opiekunów nieprofesjonalnych w celu lepszego monitorowania jego natężenia.

\section{Piśmiennictwo}

1. Zimmermann-Górska I, Andrysiak R, Brzosko M, Filipowicz-Sosnowska A. Postępy Reumatologii Klinicznej. Warszawa: PZWL; 2014. 43-63.

2. Zimmermann-Górska I. Reumatologia-postępy 2013. Med. Prakt. 2014; 4: 36-47.

3. Głuszko P, Filipowicz-Sosnowska A, Tłustochowicz W. Reumatoidalne zapalenie stawów. Reumatologia 2012; 2: 83-90.

4. Zimmermann-Górska I. Reumatologia kliniczna. Warszawa: PZWL; 2008. 495-517.

5. Wiland P., Maciążek-Chyra B. Stan reumatologii w Polsce w 2012 roku. Reumatologia 2012; 4: 263-275.

6. Bączyk G, Gacek L. Ocena sprawności funkcjonalnej chorych na reumatoidalne zapalenie stawów na podstawie funkcjonalnego testu $z$ wystandaryzowanym wyposażeniem. Reumatologia 2011; 1: 40-61.
7. Traczewski P. Reumatoidalne zapalenie stawów: ocena aktywności choroby i wyników leczenia. Med Dypl. 2011; 10: 35-40.

8. Chandrashekara S, Rajendran A, Bai Jaganath A, Krishnamurthy $R$. Neutrophil-lymphocyte ratio, pain perception, and disease activity score may serve as important predictive markers for sustained remission in rheumatoid arthritis. Reumatismo 2015; 67(3): 109-115.

9. Walden-Gałuszko K, Majkowicz M, Janiszewska J, Jankowska B. Uwarunkowania psychologiczne percepcji bólu przewlekłego. Badanie porównawcze chorych z różnym patomechanizmem bólu. Psychoonkologia 2008; 12, 1: 1-6.

10. Domżał TM. Ból przewlekły - problemy kliniczne i terapeutyczne. Pol. Prz. Neurol. 2008; 4 (1): 1-8.

11. Żuk B, Księżopolska-Orłowska K. Ochrona stawów w reumatoidalnym zapaleniu stawów. Czynności dnia codziennego. Reumatologia 2009; 4: 193-201.

12. Kłak A, Mińko M, Siwczyńska D. Metody kwestionariuszowe badania jakości życia. Probl. Hig. 2012; 93(4): 632-638.

13. Papuć E. Jakość życia - definicje i sposoby jej ujmowania. Curr Probl. Psychiatry. 2011; 12 (2): 141-145.

14. Juczyński Z. Koncepcje i pomiar jakości życia związanej ze zdrowiem. Zesz Nauk WSHE. 2004; 44: 7.

15. Miniszewska J, Chodkiewicz J, Zalewska-Janowska A. Jakość życia w zdrowiu i chorobie - czym jest, jak i po co ją oceniać. Prz Lek 2012; 69: 6.

16. Happach M, Moskalewicz B, Krzemińska-Dąbrowska I, Świerocka K. i wsp. Społeczny kontekst przewlekłego bólu $\mathrm{u}$ chorych na reumatoidalne zapalenie stawów. Reumatologia 2006; 44,4: 199-204.

17. Wieczorowska-Tobis K, Talarska D. Geriatria i pielęgniarstwo geriatryczne. Podręcznik dla studiów medycznych. Warszawa: PZWL; 2008. 212-236.

18. Ejdys M. Problemy zdrowotne i pielęgnacyjne pacjentów z zapalnymi układowymi chorobami tkanki łącznej. Pielęgniarstwo w systemie zarządzania opieką zdrowotną. Nowe wyzwania, nowe możliwości. Przeds Zarz 2012; tom XIII, zeszyt 11: $31-40$

19. Lee Y.C. Effect and treatment of chronic pain in inflammatory arthritis. Curr Rheumatol Rep. 2013; 15 (1): 300.

20. Wysocka-Skurska I, Sierakowska M, Sierakowski S. Ocena jakości życia pacjentów z reumatoidalnym zapaleniem stawów w zależności od stosowanej terapii farmakologicznej. Reumatologia 2012; 50, (1): 16-23.

Artykuł przyjęty do redakcji: 20.06.2016

Artykuł przyjęty do publikacji: 23.11.2016

Źródło finansowania: Praca nie jest finansowana z żadnego źródła. Konflikt interesów: Autorzy deklarują brak konfliktu interesów.

Adres do korespondencji:
Aldona Wróbel
ul. Polonijna 11/117
30-669 Kraków
tel.: 600525040
e-mail: aldona_kedziora@wp.pl
Uniwersytet Jagielloński Collegium Medicum

